\title{
Klasszikus galactosaemia dietetikai kezelési lehetőségei
}

\author{
Kiss Erika $\mathrm{MSc}^{1}$ - Balogh Lídia dr. ${ }^{1}$ - Reismann Péter dr. ${ }^{2}$ \\ Semmelweis Egyetem, Általános Orvostudományi Kar, ${ }^{1}$ I. Gyermekgyógyászati Klinika, \\ ${ }^{2}$ II. Belgyógyászati Klinika, Budapest
}

\begin{abstract}
A klasszikus galactosaemia a szénhidrát-anyagcsere örökletes megbetegedése, amelynek hátterében a legtöbb esetben a galaktóz-1-foszfát-uridil-transzferáz enzim defektusa áll. A súlyos klinikai tünetek már egy-két nappal a szoptatás megkezdését követően jelentkeznek: a máj megnagyobbodása és funkciózavara, sárgaság, hányás, hasmenés, idegrendszeri károsodás, vesekárosodás, infekció, szepszis, amelyek megfelelő diagnózis és kezelés nélkül akár halálhoz is vezethetnek. A betegség 1975 óta része az újszülöttkori tömegszürésnek, ezért az érintett újszülötteket pár napos életkorban kiemelik, és a kezelés idejekorán bevezetésre kerülhet. A galactosaemia jelenlegi terápiája az élethosszig tartandó laktózmentes, galaktózszegény étrend, amelynek alapja a nagy mennyiségú galaktózt tartalmazó élelmiszerek eliminálása a táplálkozásból. A tömegszürés és az élethosszig tartó gondozás eredményeként az 1975 óta kiszưrt galactosaemiás betegek megfelelő diéta mellett jó szomatomentális állapotot érnek el, amely alapját képezi az önálló felnőttéletvitelnek.

Orv Hetil. 2017; 158(47): 1864-1867.
\end{abstract}

Kulcsszavak: galactosaemia, diéta, veleszületett anyagcsere-betegség, laktóz

\section{Diet treatment of classical galactosemia}

\begin{abstract}
Classical galactosemia is an inherited disorder of the carbohydrate metabolism, most often caused by the deficient activity of the enzyme galactose-1-phosphate-uridyltransferase. Classical galactosemia presents in the neonatal period with life threatening illness after galactose is introduced in the diet. Symptoms and signs include poor feeding, vomiting, and diarrhea, weight loss, jaundice, hypotension, cataracts, hepatosplenomegaly, hepatocellular insufficiency, and encephalopathy. Since 1975 the testing for galactosemia is part of the neonatal screening program in Hungary. Affected newborns are recognized in the first days of their life, and special diet is introduced immediately. The therapy of galactosemia is the lactose-free and galactose-poor diet for life. As a result of the nationwide newborn screening and the lifelong medical therapy, early treatment with galactosemia can achieve a normal life without serious complications.
\end{abstract}

Keywords: galactosemia, diet, inborn errors of metabolism, lactose

Kiss E, Balogh L, Reismann P. [Diet treatment of classical galactosemia]. Orv Hetil. 2017; 158(47): 1864-1867.

(Beérkezett: 2017. augusztus 18.; elfogadva: 2017. szeptember 21.)

\section{Rövidítések}

G-1-P = glükóz-1-foszfát; G-6-P = glükóz-6-foszfát; G-6-PDH = glükóz-6-foszfát-dehidrogenáz; GALK = galaktokináz; GAL-1-PUT vagy GALT = galaktóz-1-foszfát-uridil-transzferáz; UDP-galaktóz = uridil-difoszfát-galaktóz; UDP-glükóz = uridil-difoszfát-glükóz

A galaktóz metabolizmusában szerepet játszó enzimek valamelyikének öröklött hiánya vagy csökkent múködése következtében a vérben és a szövetekben felszaporodik a galaktóz-1-foszfát vagy a galaktikol, amely irreverzibilis módon károsítja a szerveket, kezeletlen esetben súlyos szellemi és testi retardációhoz vezet [1].

Az időben elkezdett táplálásterápiás kezeléssel sokszor teljesen, némely esetben csak részlegesen meg lehet akadályozni a kóros folyamatok kialakulását.

A galaktóz a laktóz lebontási terméke. A laktóz (anyatej, tehén-, kecske-, juhtej, tehéntejalapú tápszerek) a bélben glükózra és galaktózra bomlik. A galaktóz uridildifoszfát-glükózzá (UDP-glükóz) alakul enzimatikus fo- 


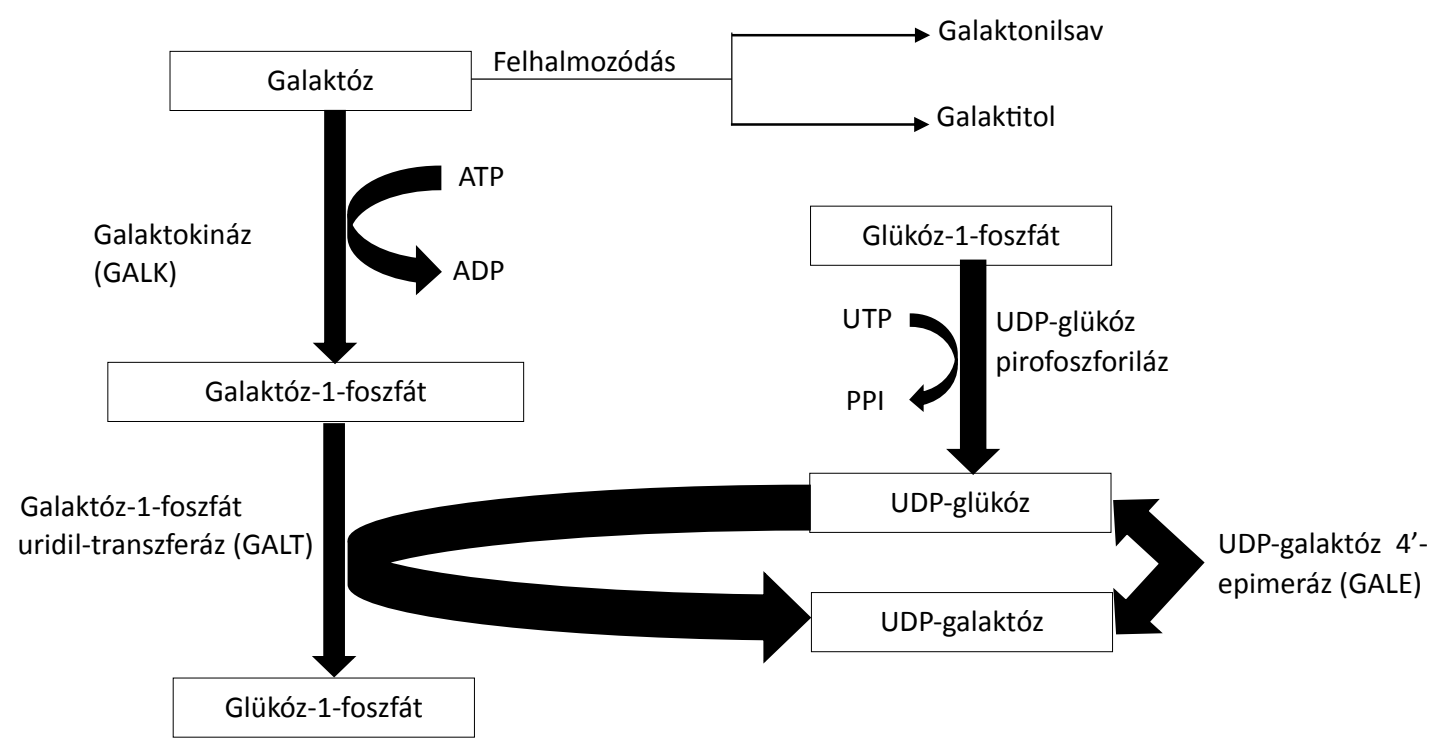

1. ábra

\begin{tabular}{|l} 
A galaktóz anyagcsereútja \\
Forrás alapján: Fernandes, Saudubray, Van den Berghe, Walter. Inborn metabolic disease, diagnosis and treatment. 2006 p. 54. \\
ADP = adenozin difoszfát; ATP = adenozin trifoszfát; PPI = protinpumpa inhibitor; UDP = uridil-difoszfáz; UTP = uridil-transzferáz
\end{tabular}

lyamatok révén (1. ábra). Ennek létrejöttében három enzim játszik szerepet:

- galaktokináz,

- galaktóz-1-foszfát-uridil-transzferáz (GAL-1-PUT),

- uridil-difoszfát-galaktóz-4-epimeráz.

\section{Genetika, incidencia}

A galactosaemia autoszomális recesszív módon öröklődik. Mind az anya, mind az apa klinikai szempontból döntően tünetmentes, de egyes heterozigóta személyeknél lehetnek enyhe tünetek. A különböző országokban, etnikumokban más és más a galactosaemia incidenciája, míg Japánban ez a betegség rendkívül ritka, egymillió emberből egy galactosaemiás, addig hazánkban ez az arány 1:40 000 [2].

A legsúlyosabb a galaktóz-1-foszfát-uridil-transzferáz (GAL-1-PUT-) defektus. A GALT gén a 9. kromoszómán helyezkedik el (9pl3), jelenleg körülbelül 340 mutációját ismerjük. Európában a két leggyakoribb mutáció a Q188R és a $K 285 N$ (a betegek 70\%-a) [3]. A genetikai eltérés meghatározza a residualis enzimaktivitást, ez alapján súlyosabb és enyhébb galactosaemia különíthető el. Az enyhe formában (Duarte-variáns) mintegy 50\%-os enzimaktivitással rendelkezik a beteg. Az úgynevezett kettős heterozigóták (compound heterozigóta) egyik génje a klasszikus galactosaemiára, a másik a Duarte-variánsra hajlamosít, és ezáltal a beteg enzimaktivitása csak 25\%-os [4]. A residualis enzimaktivitás ismerete segít a táplálásterápia beállításában [5].
A galaktokináz-defektus esetén galactosuria jelentkezik, valamint korai cataracta kialakulásához vezet.

A szürke hályog kialakulásakor a galaktóz a szemlencse sejtjeibe szállítódik. Itt magas az aldózreduktáz enzim koncentrációja, amely egy alternatív galaktózanyagcsereútvonalat generalizál. Ennek következtében a szemlencse sejtjeiben a galaktózból galaktitol (dulcitol) képződik. A galaktitol számára a sejtmembrán nem átjárható, így a cukoralkohol a szemlencse sejtjeiben felhalmozódik. Ennek következtében a sejtek ozmotikus nyomása megnő, ami nagy mennyiségû vízfelvételt eredményez. Ez a szemlencse sejtjeinek duzzadásához, majd irreverzibilis károsodásához, cataracta, esetleg vakság kialakulásához vezet. A cataracta kialakulása laktózmentes és galaktózszegény diéta korai bevezetésével és egy életen át való betartásával elkerülhető. A galaktokináz-defektus okozta galactosaemia világszerte rendkívül ritka, gyakorisága a népességben 1:1 000 000. Azonban a roma populációban az incidencia ennek többszöröse lehet [6].

\section{Az epimerázhiány}

A betegség a galaktóztartalmú táplálást követően hypergalactosaemiával és galaktosuriával jár. A galaktóz mellett azonban galaktóz-1-foszfát és UDP-galaktóz is felhalmozódik a vérben. A szakirodalom korábban a defektus két klinikai megjelenési típusát különböztette meg. Az egyik típus a perifériás vagy benignus forma, ahol az enzimhiány a vörösvértestekre és a fehérvérsejtekre korlátozódik, azonban a májban, a bőr fibroblastsejtjeiben és az aktív lymphocytákban az enzimaktivitás normális 
szintet mutat. A betegség másik típusa a súlyos vagy más néven generalizált forma, ahol valamennyi szövetben hiányzó vagy csökkent enzimaktivitást lehet detektálni. Az előbbi típus enyhe, sokszor ki sem mutatható tüneteket eredményez, míg az utóbbinál a klasszikus galactosaemiánál tapasztalható, rendkívül súlyos klinikai szimptómák - elhúzódó sárgaság, táplálási nehézség, hányás, hasmenés, súlyvesztés, hepatomegalia - is megjelenhet. A betegség perifériás formája számos etnikumban előfordul, gyakorisága a különböző populációkban 1:6700-tól 1:60 000-ig változhat. Ezzel szemben a defektus generalizált formája világviszonylatban is rendkívül ritka [7].

\section{Veleszületett anyagcsere-betegségek újszülöttkori tömegszúrése}

Hazánkban 1975 óta kötelező jellegű a veleszületett anyagcsere-betegségek újszülöttkori tömegszürése. Kezdetben két betegséget, a phenylketonuriát és a galactosaemiát vették be a programba, majd 1984-ben a hypothyreosissal, 1989-ben a biotinidázdefektussal bővült. A kiterjesztett tömegszürési programban 2007 októberétől immár 26 anyagcsere-betegséget szűrnek. Két központban történik a szűrôvizsgálat, az ország nyugati feléből a vérminták a Semmelweis Egyetem I. Gyermekklinikájára érkeznek be, az ország keleti feléból a Szegedi Tudományegyetem Gyermekgyógyászati Klinikájára. Általában az újszülött három-öt napos életkorában kerül sor a vérvételre, amelynek eredménye néhány napon belül elérhetővé válik. Galactosaemia esetén azonnal abba kell hagyni az anyatejes vagy tápszeres táplálást, és galaktózmentes tápszerkészítményre kell áttérni [8].

\section{A dietoterápia alapelvei}

A kezelés célja a szérumgalaktózszint normalizálása, tartósan $10 \mathrm{mg} \%$ alatti értéken való tartása. Újszülöttkorban az anyatej és/vagy anyatejpótló gyógytápszer alkalmazása helyett galaktózmentes tápszert vezetünk be. A terápia élethosszig tart, amelynek alapja a laktózmentes, galaktózszegény étrend [9].

Szükséges kizárni minden olyan élelmiszert az étrendből, amely magas galaktóztartalommal bír, így elsősorban a tejet, tejterméket, belsőségeket, zöldborsót, muskotályos szőlőt. Vannak olyan élelmiszerek, amelyek rejtett formában tartalmaznak galaktózt, például galaktolipid (bab, búzasikér, rizs, paradicsom), raffinóz (kakaóbab, káposztafélék), pektincsoport (agy, vese, máj, belsőségek), laktozil-ceramid (belsóségek) és arabinogalaktózstachióz-arabinogalaktán (répa, hagyma, fokhagyma, spárga) formájában. Ezekből az élelmiszerekből szintén tilos nagy mennyiségben fogyasztani (1. táblázat).

Néhány alaptejtermék laktóz- és galaktóztartalmát mutatja be a 2. táblázat. Az életkor és a maradék enzimaktivitás ismeretében kiszámolható a naponta elfogyaszt-
1. táblázat Galactosaemiadiétában tilos és fogyasztható élelmiszerek listája

\begin{tabular}{ll}
\hline $\begin{array}{l}\text { Tilos élelmiszerek galactosaemia } \\
\text { esetén }\end{array}$ & Alternatív lehetőségek \\
\hline Anyatej & $\begin{array}{l}\text { Galaktózmentes anyatejpótló } \\
\text { készítmény }\end{array}$ \\
\hline $\begin{array}{l}\text { Anyatejpótló és/vagy tejalapú } \\
\text { gyógytápszerek }\end{array}$ & Galaktózmentes gyógytápszer \\
\hline Szójaalapú tápszerkészítmények & Galaktózmentes gyógytápszer \\
\hline Tej, tejpor (tehén, juh, kecske stb.) & $\begin{array}{l}\text { Növényi tejek: rizstej, } \\
\text { mandulatej, zabtej }\end{array}$ \\
\hline Túró & - \\
\hline Joghurt & Galaktózszegény joghurtké- \\
\hline szítmény
\end{tabular}

Forrás: Somogyi Cs, Kiss E, Milánkovics I. Mi a galaktozémia? 2004. Phare kiadvány

2. táblázat | Élelmiszerek laktóz- és galaktóztartalma

\begin{tabular}{lcc}
\hline Élelmiszer & $\begin{array}{c}\text { Laktóztartalom } \\
(\mathrm{mg} / 100 \mathrm{~g} \\
\text { élelmiszerben })\end{array}$ & $\begin{array}{c}\text { Galaktóztartalom } \\
(\mathrm{mg} / 100 \mathrm{~g} \\
\text { élelmiszerben })\end{array}$ \\
\hline Tehéntej & 4400 & 2200 \\
Tej, laktózmentes & 20 & 1650 \\
Joghurt & 4400 & 2200 \\
Tejszín & 2200 & 1100 \\
Vaj & 600 & 300 \\
Csokoládé, tej & 10100 & 5100 \\
Jégkrém, tejes & 5200 & 2600
\end{tabular}

Forrás: Acosta PB, Gross KC. Hidden sources of galactose in the environment. Eur J Pediatr. 1995; 154(7 Suppl 2): S87-S92.

ható galaktózmennyiség, amely 50-500 mg között lehet (3. táblázat).

$\mathrm{Az}$ étrendi megszorítások mellett a gyógyszerek laktóztartalmára is fontos odafigyelni, mivel a legtöbb tab- 
lettázott termék vivőanyaga a laktóz, így olyan helyettesítő terméket célszerü választani, amely laktózmentes. Elsősorban azoknál a gyógyszerkészítményeknél fontos ez a megkötés, amely hosszú távon kerül alkalmazásra (vitaminok, fogamzásgátló stb.) [10].

Élelmiszerek esetében tévhit, hogy a laktózmentes termékek alkalmasak lennének ebben a diétában. A laktózmentesség ebben az esetben azt jelenti, hogy a diszacharidkötést felbontják, de így a termékben ugyanúgy benne marad a glükóz is és a galaktóz is, összességében egyáltalán nem csökken a galaktóztartalma. Ennek megfelelően nem illeszthető be a diétába a laktózmentes tej, tejföl, túró stb. [11]. Pácienseink az élethosszig tartandó diétát nagy fegyelemmel tartják be, a diétahiba előfordulása minimális, mivel olyan aktív tünetekkel jár a „melléevés”, amelyet több alkalommal nem követnek el. Nagy menynyiségű galaktóztartalmú étel elfogyasztása után hasmenés, hányás, gastrointestinalis tüneteket tapasztalnak.

\section{Pótlás}

Annak érdekében, hogy hiánytünetek ne alakulhassanak ki az eliminációs étrend következtében, a kalciumbevitelre fokozott figyelmet kell fordítani. A napi szükséges kalciummennyiséget, amely ugyanannyi, mint egészséges kortársaiké, elsősorban halakból, halkészítményekből, olajos magvakból, kalciummal dúsított ásványvizekből, galaktózmentes gyógytápszerekből, valamint növényi tejkészítményekből (zabtej, rizstej, mandulatej) lehet pótolni. Ha ezek mennyisége nem elégséges, vagy felszívódásuk elégtelen, akkor kalciumpótló készítmények alkalmazására kerülhet sor. D-vitamin beviteléből is mértékadó az egészséges kortársaiké. Az elégtelen kalciumbevitelre az alkalikus foszfatáz emelkedett értéke utal.

A galaktózszint nyomon követése érdekében a betegek rendszeresen szűrőpapíros vér- és vizeletmintát küldenek a szűrőközpontokba, ahol a galaktóz- és a galaktóz-1-foszfát-szintek monitorizálásával lehet ellenőrizni a diéta megfelelő betartását. Időszakos szakorvosi, diete-

3. táblázat |Életkor-specifikus galaktózbeviteli értékek

\begin{tabular}{lc}
\hline Életkor & $\begin{array}{c}\text { Napi engedélyezett galaktózbevitel } \\
(\mathrm{mg})\end{array}$ \\
\hline Csecsemőkor & $50-200$ \\
Kisgyermekkor & $150-200$ \\
Serdülőkor & $200-300$ \\
Felnőttkor & $250-500$ \\
\hline
\end{tabular}

Forrás: Schweitzer S, Pryzembel H, Urrrich K, et al. Empfehlung der Arbeitsgemeinschaft für Pädiatrische Stoffwechselstörungen (APS) zur Behandlung der Galaktosämie. In: Thauer E, Bake G. (eds) Galaktosämie. Jubileumsausgabe. Elterninitiative Galaktosämie e. V., Düsseldorf, 1998; pp. 21-24. tikai, pszichológiai és a társszakmák szakorvosainak ellenőrzése szükséges. Ezen kontrollok során a lehetséges szövődmények irányába kell szürni a beteget, igény szerint megfelelő kezelés indítása szükséges. A beteg, illetve családtagjainak edukációja központi szerepet foglal el az élethosszig tartó gondozáson és kezelésen belül. Megfelelő diéta mellett a galaktózszint tartósan a céltartományban tartható, amely alapvető a minél jobb szomatomentális fejlődéshez, hogy a galactosaemiás páciens is teljes értékü életet élhessen [2, 12].

Anyagi támogatás: A közlemény megírása anyagi támogatásban nem részesült.

Szerzői munkamegosztás: A szerzők egyenlő arányban járultak hozzá a közlemény elkészítéséhez. A cikk végleges változatát mindhárom szerző elolvasta és jóváhagyta.

Érdekeltségek: A szerzőknek nincsenek érdekeltségeik.

\section{Irodalom}

[1] Guthrie R. The origin of newborn screening. Screening 1992; 1: 5-15.

[2] V. Shaw. (ed.) Clinical paediatric dietetics (4th edn.), WileyBlackwell, 2014; pp. 526-540.

[3] Mönch E, Link R. (eds.) Diagnostik und Therapie bei angeborenen Stoffwechselstörungen. SPS Verlagsgesellschaft $\mathrm{mbH}$, Heilbronn, 2002.

[4] Zschocke J, Hoffmann GF. (eds.) Vademecum Metabolicum: Diagnosis and treatment of inborn errors of metabolism. 3rd edn. Milupa Metabolics GmbH, Friedrichsdorf, 2011.

[5] James PM, Levy HL. The clinical aspects of newborn screening: importance of newborn screening follow-up. Ment Retard Dev Disabil Res Rev. 2006; 12: 246-254.

[6] Milánkovics I, Csókay B, Kámory E, et al. Molecular analysis of Hungarian patients with galactosaemia by direct sequencing. SSIEM, 42st Annual Symposium, Paris, 2005.

[7] Wachtel U, Hilgarth R. (eds.) Ernährung und Diätetik in Pädiatrie und Jugendmedizin. Georg Thieme Verlag, Stuttgart, 2005.

[8] Acosta PB, Yannicelli S. The ross metabolic formula system nutrition support protocols. Ross Laboratories, 4th edn. Abbott Laboratories, Columbus, Ohio, 2001.

[9] Howell RR, Engelson G. Structure for clinical follow-up: Newborn screening. J Inherit Metab Dis. 2007; 30: 600-605.

[10] Van Calcar SC. A re-evaluation of life-long severe galactose restriction for the nutrition management of classic galactosemia. Mol Genet Metab. 2014; 112: 191-197.

[11] Van Calcar SC, Bernstein LE, Rohr FJ. Galactose content of legumes, caseinates, and some hard cheeses: implications for diet treatment of classic galactosemia. J Agric Food Chem. 2014; 62: 1397-1402.

[12] Fernandes J, Saudubray JM, Berghe GVD, et al. (edn.) Inborn metabolic diseases: diagnosis and treatment. Springer Verlag, Heidelberg, 2006; pp. 54.

(Kiss Erika,

Budapest, Bókay J. u. 53.,1083 e-mail: kiss.erika@med.semmelweis-univ.hu) 